BMC

Genomics

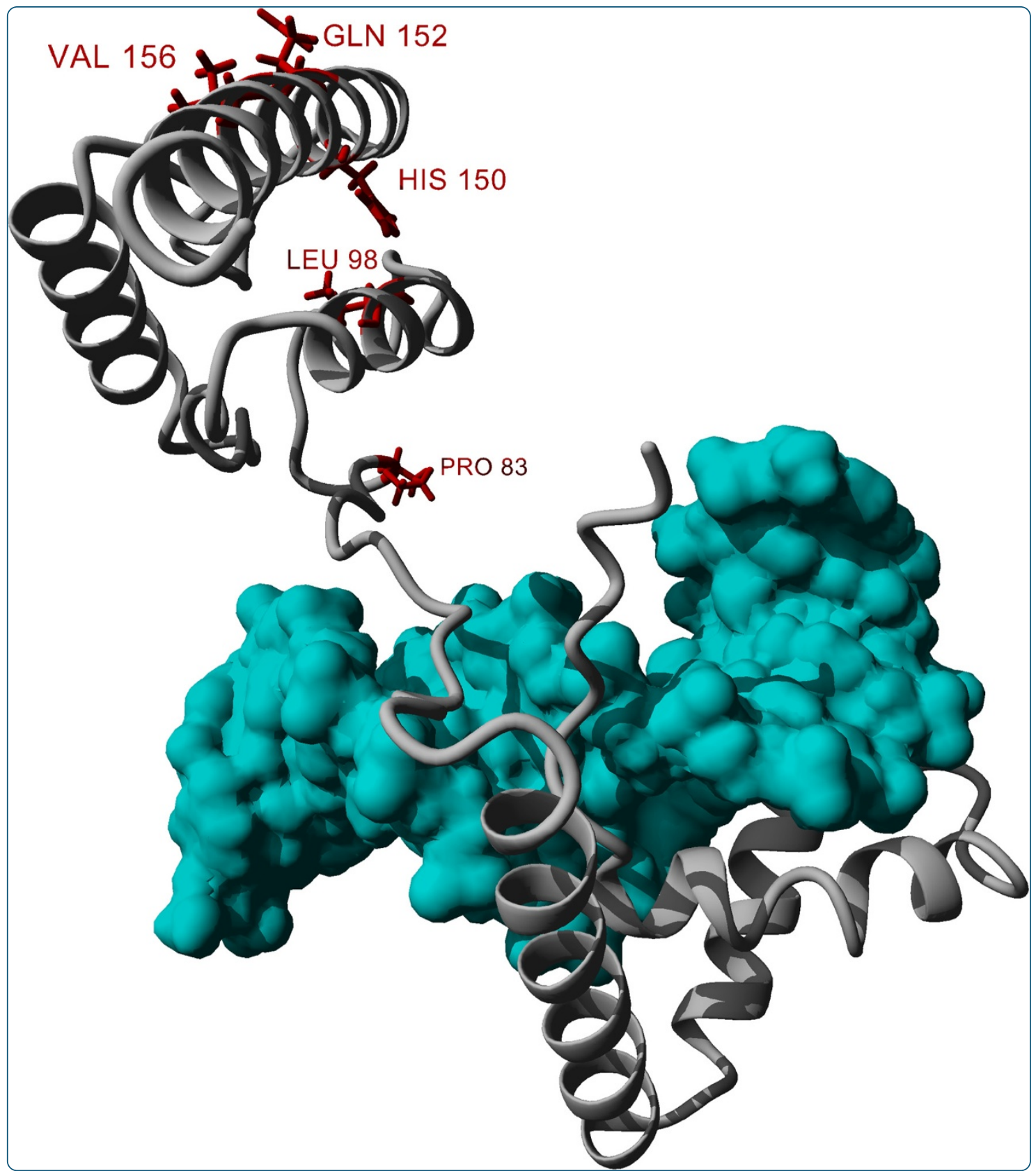

\title{
Analysis of Sry duplications on the Rattus norvegicus Y-chromosome
}

Prokop et al. 


\title{
Analysis of Sry duplications on the Rattus norvegicus Y-chromosome
}

\author{
Jeremy W Prokop ${ }^{1,2,3}$, Adam C Underwood ${ }^{4}$, Monte E Turner ${ }^{1,2}$, Nic Miller ${ }^{1}$, Dawn Pietrzak', Sarah Scott', \\ Chris Smith ${ }^{1}$ and Amy Milsted ${ }^{1,2^{*}}$
}

\begin{abstract}
Background: Gene copy number variation plays a large role in the evolution of genomes. In Rattus norvegicus and other rodent species, the Y-chromosome has accumulated multiple copies of Sry loci. These copy number variations have been previously linked with changes in phenotype of animal models such as the spontaneously hypertensive rat (SHR). This study characterizes the Y-chromosome in the Sry region of Rattus norvegicus, while addressing functional variations seen in the Sry protein products.

Results: Eleven Sry loci have been identified in the SHR with one (nonHMG Sry) containing a frame shift mutation. The nonHMGSry is found and conserved in the related WKY and SD rat strains. Three new, previously unidentified, Sry loci were identified in this study (Sry3BII, Sry4 and Sry4A) in both SHR and WKY. Repetitive element analysis revealed numerous LINE-L1 elements at regions where conservation is lost among the Sry copies. In addition we have identified a retrotransposed copy of Med14 originating from spliced mRNA, two autosomal genes ( $C c d c 110$ and HMGB1) and a normal mammalian Y-chromosome gene (Zfy) in the Sry region of the rat Y-chromosome. Translation of the sequences of each Sry gene reveals eight proteins with amino acid differences leading to changes in nuclear localization and promoter activation of a Sry-responsive gene. Sry- $\beta$ (coded by the Sry2 locus) has an increased cytoplasmic fraction due to alterations at amino acid 21. Sry- $\gamma$ has altered gene regulation of the Sry 1 promoter due to changes at amino acid 76.

Conclusions: The duplication of Sry on the Rattus norvegicus Y-chromosome has led to proteins with altered functional ability that may have been selected for functions in addition to testis determination. Additionally, several other genes not normally found on the Y-chromosome have duplicated new copies into the region around the Sry genes. These suggest a role of active transposable elements in the evolution of the mammalian Y-chromosome in species such as Rattus norvegicus.
\end{abstract}

Keywords: Y-chromosome, Sry, SHR, Rattus norvegicus, Copy number variations, Y-chromosome evolution

\section{Background}

The testis determining gene Sry on the mammalian Y-chromosome triggers the testis development pathway in placental mammals [1]. It encodes a protein that is composed of a highly conserved three helix HMG domain with additional hinge and bridge domains. Variations are found in the $\mathrm{N}$ - and $\mathrm{C}$-terminal domains among species. In most mammals, Sry is found as a single locus; however, rodent species [2-5], have been reported to show copy number

\footnotetext{
* Correspondence: milsted@uakron.edu

'Department of Biology, The University of Akron, 302 Buchtel Commons, 44325-3908 Akron, OH, USA

${ }^{2}$ Program in Integrated Bioscience, The University of Akron, 44325 Akron, $\mathrm{OH}$, USA

Full list of author information is available at the end of the article
}

variation (CNV). CNV of Sry has been detected in humans exposed to radiation or those with sex chromosome related anomalies [6,7]. In Rattus norvegicus, multiple loci of Sry are expressed and code for proteins with altered amino acid sequences [8]. These loci have been suggested to function in the development of increased blood pressure in the Spontaneously Hypertensive Rat (SHR) compared to the normotensive Wistar Kyoto (WKY) [9]. One locus, Sry3, has been detected in SHR but not in WKY, and codes for a protein that has amino acid differences altering promoter regulation of renin-angiotensin system genes [10]. The entire rat Y-chromosome for Rattus norvegicus has yet to be assembled, thus limiting full understanding of gene duplication and divergence of Sry copies. Using newly deposited BAC clone sequences from the SHR rat strain (SHR/Akr),

\section{Biomed Central}


we have localized the Sry copies relative to each other, identifying several new Sry loci. The multiple copies of Sry code for proteins with amino acid variations resulting in functional changes to promoter activity and nuclear localization.

\section{Results}

\section{Identification of Sry Copies in the Rattus norvegicus} SHR strain

Several BAC sequences for the SHR/Akr Y chromosome have been deposited in Genbank. We have combined our past analyses of Sry in this strain with these new sequences, to identify contigs that include various Sry loci (Table 1). The current number of identified Sry loci in Rattus norvegicus is eleven. The novel eleventh locus we have designated as nonHMG Sry due to a frame shift mutation yielding a protein with an incomplete HMG box.

The assembly of the Sry region has resulted in two aligned contigs of $432 \mathrm{~kb}$ and $377 \mathrm{~kb}$, respectively. Using these contigs, the location and identity of multiple Sry loci were mapped (Figure 1). The first contig (Contig 1) contains Sry4, nonHMG Sry and Sry $4 A$ while the second (Contig 2) contains Sry1, Sry3C, Sry3B, Sry3BII, Sry2, and Sry $3 A$. In addition to the Sry loci found in these two contigs, two additional previously identified Sry loci (Sry3 and Sry3BI) did not map to either contig. Repeatmasker identified a high level of LINE L1 elements in both Contig 1 (31.38\%) and Contig 2 (32.77\%) relative to DNA sequence flanking the single copy of human $S R Y$ ( $h S R Y, 18.88 \%$ ) or mouse Sry (mSry, 17.70\%,) (Additional file 1: Figures S1-S4). Alignment of sequences for the multiple rat Sry loci reveals regions conserved among the various copies (Additional file 1: Figure S5). Many of the sites where homology is lost are flanked by LINE L1 elements (blue, Figure 1). Phylogenetic analysis using the sequence conserved in Sry copies in these contigs shows clustering of the Sry3 loci (3BII, 3A, 3B, 3C) and a separate clustering of Sry 4 and Sry $4 A$ (Additional file 1: Figure S6).

\section{Newly identified Sry copies in other Rattus norvegicus strains}

Four novel Sry sequences (nonHMG Sry, Sry4, Sry 4 A and Sry3BII) were identified in the SHR/Akr in this paper. Of these, the nonHMG Sry sequence was confirmed from genomic DNA, with 100\% sequence homology in SHR/ Akr [GenBank: KC215139], WKY/Akr [KC215140], and SD/hsd [KC215141] strains. Sry4, Sry4A and Sry3BII were confirmed in both SHR/Akr and WKY/Akr strains using PCR reactions and selective restriction digests designed to differentiate loci based on PCR products (Additional file 1: Figure S7).

\section{Identification of other loci in the Sry region of the SHR Y-chromosome}

The zinc finger on the $Y(Z f y)$ locus is found between Sry4 and the nonHMG Sry. This locus is found on many other mammalian Y-chromosomes near Sry. In addition to $Z f y$, we have identified a possible Med14 locus between Sry4 and the nonHMG Sry. Normally Med14 is found on the mammalian X-chromosome, where it contains 31 exons separated by large introns. The form identified on the Y-chromosome of SHR is spliced, containing 30 of the normal 31 exons of the long form Med14 of the Xchromosome (Additional file 1: Figure S8). Located $1 \mathrm{kB}$ from the Med14Y sequence (red, Figure 1) is an LTR/ ERVK element (purple, Figure 1). The presence of both an LTR element and spliced exons suggests that this copy has been retrotransposed onto the Y-chromosome. The protein coded by Med14Y would be highly homologous to the X-chromosome Med14 (Additional file 1: Figure S9) if it could be transcribed and translated. In addition to

Table 1 BAC sequences used to assemble the Sry region of the SHR Y-chromosome

\begin{tabular}{|c|c|c|c|c|c|c|}
\hline BAC & Sry gene(s) & BAC status & Library & Fragments & Bases & Date deposited \\
\hline AC242859 & Sry3A & Complete & RNAEX & 1 & 99871 & Dec 2010 \\
\hline AC239701 & Sry 4 & Complete & RNAEX & 1 & 138396 & Dec 2010 \\
\hline AC239865 & nonHMG, Sry $4 A$ & Complete & RNAEX & 1 & 268785 & Dec 2010 \\
\hline AC239814.3 & Sry 4 & working draft & RNAEX & 1 & 331097 & Sept 2011 \\
\hline AC239817 & $\operatorname{Sry} 3 B$ & Complete & RNAEX & 1 & 97422 & Dec 2010 \\
\hline AC239866.3 & nonHMG & working draft & RNAEX & 23 & 92289 & Feb 2010 \\
\hline AC243747.5 & $\operatorname{Sry} 3 C, \operatorname{Sry} 3 B$ & working draft & RNECO & 7 & 165825 & Apr 2011 \\
\hline AC243673 & Sry3C Sry $4 A$ & working draft & RNECO & 13 & 153940 & Apr 2011 \\
\hline AC243442 & Sry4A, Sry3C, Sryl & working draft & RNECO & 11 & 100422 & Dec 2010 \\
\hline AC242641 & Sry3A, SryzBI & working draft & RNECO & 6 & 144578 & Sep 2010 \\
\hline AC241808.7 & Sry3B, Sry3BII, Sry2 & Complete & RNECO & 1 & 156555 & Jun 2011 \\
\hline AC240535 & Sry3Bll, Sryz & Complete & RNECO & 1 & 153894 & Dec 2010 \\
\hline
\end{tabular}




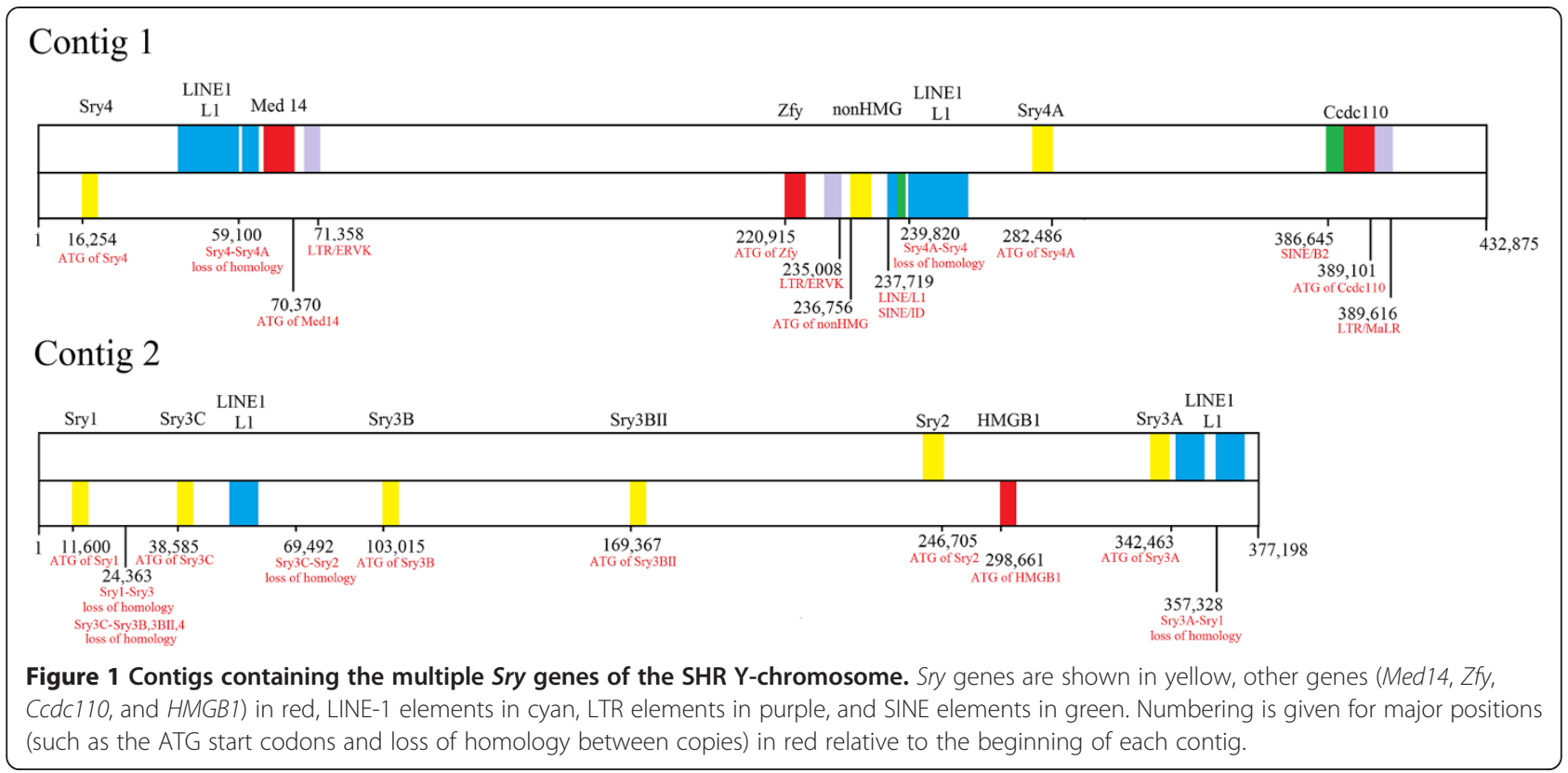

Med14Y, we have identified a Ccdc110-like locus (Contig 1, after Sry4A) and a HMGB1-like locus (Contig 2, between Sry 2 and Sry3A, Figure 1).

\section{Sry protein sequence comparison}

Translating each of the Sry loci into protein sequences (Table 2) allows for comparison of amino acid variations. The eleven Sry loci can be translated into nine (Sry $\alpha-S r y \theta$ and nonHMG Sry) different protein sequences. Several Sry loci encode the same protein sequence; therefore, we created a new naming system for the Sry proteins using Greek letters to help to differentiate protein naming from the Sry loci naming. The Sry3/Sry3C (Sryy used to symbolize the protein) and Sry3B/Sry3BII (Srye) loci translate to the same protein sequences (Figure 2). Sequence alignments of all Sry proteins reveal variation at amino acids 4,21 ,
38, 76, 83, 98, 150, 152, 156 and in the Q-repeat length of the C-terminus. The nonHMG Sry codes for a highly divergent sequence containing the first helix and nuclear localization site of normal Sry (red, Figure 3), but due to a frame shift mutation the sequence diverges after this region. This protein sequence following the frame shift mutation contains a high level of Lys and Gln amino acids (Figure 3), indicating a high potential for interactions with other proteins.

Using the DNA sequence, starting at the ATG start codon and extending through the stop codon of each Sry copy, phylogenetic analysis was performed comparing rat Sry copies to Muennink's Spiny rat (Tokudaia muenninki) copies, $m S r y$, and $h S R Y$ (Figure 4). All the proteins coded by the Sry3 loci (Sryy-Sryל) cluster together (as also confirmed through conserved amino acids), as do those from

Table 2 Sry proteins encoded on the SHR Y-chromosome with GenBank accession codes

\begin{tabular}{ccccc}
\hline Sry gene & Sequenced BACs (s) & Protein product & Confirmed sequence in SHR/Akr & Confirmed sequence in WKY/Akr \\
\hline nonHMG Sry & AC239865.4 & Predicted & KC215139 & KC215140 \\
Sry1 & AC243442 & $a$ & EU984075 & FJ168067 \\
Sry2 & AC240535.5 & $\beta$ & FJ168057 & FJ168068 \\
Sry3 & Not yet identified in BACs & $\gamma$ & EU984077 & Unconfirmed \\
Sry3A & AC242859.2 & $\delta$ & EU984078 & FJ168069 \\
Sry3B & AC241808.7, AC239817.2 & $\varepsilon$ & FJ168058 & FJ168070 \\
Sry3Bl & AC242641 & $\zeta$ & FJ168059 & FJ168071 \\
Sry3Bll & AC240535.5, AC241808.7 & $\varepsilon$ & Present & Present \\
Sry3C & AC243442 & $Y$ & EU984076 & FJ168072 \\
Sry4 & AC239701.6 & $\eta$ & Present & Present \\
Sry4A & AC239865.4 & $\theta$ & Present & Present \\
\hline
\end{tabular}




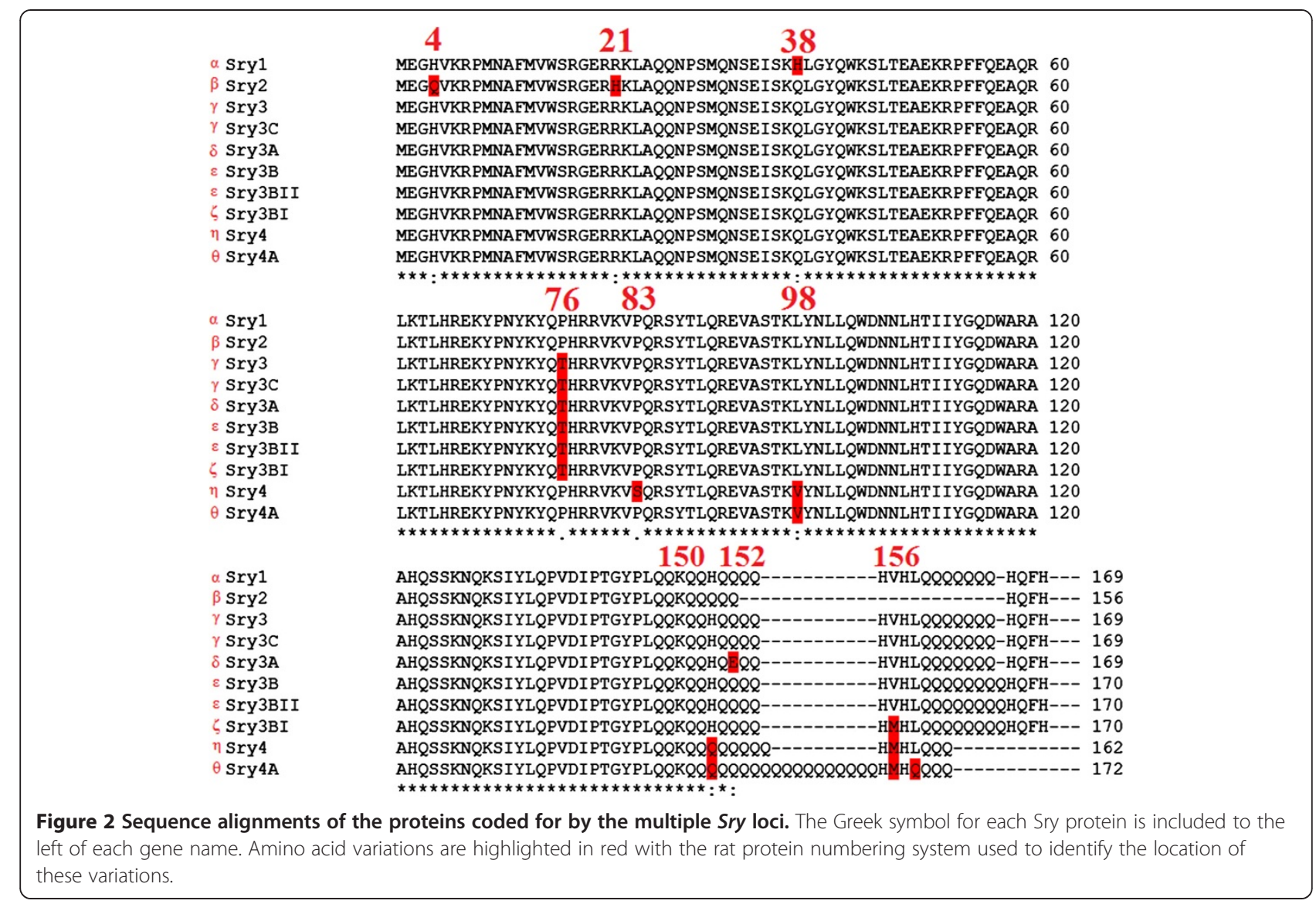

Sry4 and Sry4A (Sryn-Sry $\theta)$, similar to the analysis done using the maximally conserved sequences (Additional file 1: Figure S6). The phylogenetic analysis suggests the possibility that a Sry locus, present before the Sry2 split from Sry1, Sry 4 and Sry4A, may have been the original locus in rodents prior to copy number increase.
Inspection of individual amino acids found in the rat Sry copies when compared to human and mouse protein sequences supports this claim (Figure 2 and Additional file 1: Figure S10). As expected, the nonHMG Sry sequence is highly divergent from all other Sry, a likely result of drift following the frame shift mutation.

\section{MEGHVKRPMNAFMVWSRGERHKWPNGPAEYPACKIQTSADSWDISGKTLQKPKKKKKTQQ QQQKNQPFLSGGTRTYTERNTQNIRISLIGGQKCHREWQPAAVGQQRTHHHIQIMTEVEQ PTCPPRTWERAEIFLVEKTN \\ Number of amino acids: 140 \\ Molecular weight: 16337.6 \\ Theoretical pI: 10.18 \\ Ext. coefficient 30605 \\ The estimated half-life \\ is: 30 hours (mammalian reticulocytes, in vitro)

\begin{tabular}{|c|c|c|c|}
\hline Ala & (A) & 7 & 5.08 \\
\hline Arg & (R) & 10 & 7.18 \\
\hline Asn & (N) & 6 & 4.38 \\
\hline Asp & (D) & 2 & 1.48 \\
\hline Cys & (C) & 3 & 2.18 \\
\hline Gin & (Q) & 15 & 10.78 \\
\hline Glu & (E) & 8 & 5.78 \\
\hline Gly & (G) & 9 & 6.48 \\
\hline His & (H) & 6 & 4.38 \\
\hline Ile & (I) & 8 & 5.78 \\
\hline Leu & (L) & 4 & 2.98 \\
\hline Lys & (K) & 13 & 9.38 \\
\hline Met & (M) & 4 & 2.98 \\
\hline Phe & (F) & 5 & 3.68 \\
\hline Pro & (P) & 10 & 7.18 \\
\hline Ser & (S) & 6 & 4.38 \\
\hline Thr & (T) & 12 & $8.6 \%$ \\
\hline $\operatorname{Trp}$ & (W) & 5 & $3.6 \%$ \\
\hline TYx & (Y) & 2 & 1.48 \\
\hline Val & (V) & 5 & $3.6 \%$ \\
\hline
\end{tabular}

Figure 3 Sequence of the nonHMG Sry with ProtParam statistics. Sequence shows the conserved first helix of the HMG box in red, followed by a frame shift mutation leading to a different protein sequence. The predictions for molecular weight, pl, and extinction coefficient are given. This protein sequence contains a high percentage of Gln (10.7\%) and Lys (9.3\%) as can be seen in the amino acid percentages. 


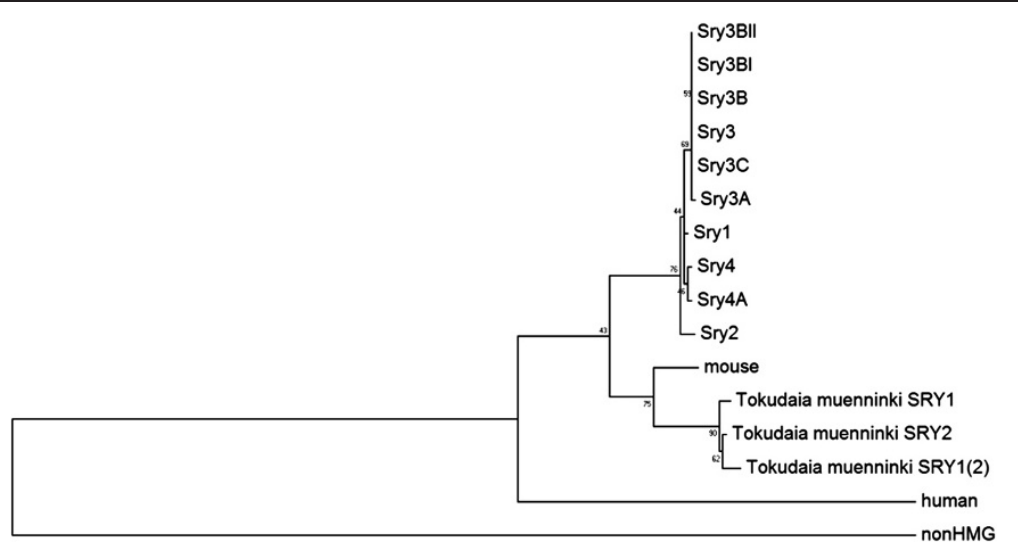

Figure 4 Phylogenetic analysis of the coding region of the multiple rat Sry. Phylogenetics of the coding region of the rat Sry genes compared to the mouse Sry, three copies of Tokudaia muenninki, human and the nonHMG. Numbers next to each node represent the percent of the 500 bootstrap phylogenies that were identified similar to the one shown in the figure.

\section{Sry protein functional variations}

To analyze functional variation of amino acid differences in the multiple Sry proteins, this study used both modeling and site directed mutagenesis. Three amino acid sites differ in the HMG box (amino acids 4, 21 and 38; Figure 2 and Additional file 1: Figure S10) and an additional amino acid site in the highly conserved hinge domain (amino acid 76; Figure 2 and Additional file 1: Figure S10). Amino acids 4, 21, and 76 additionally fall into nuclear localization signal sites $[11,12]$. Using a modeled structure of the protein coded by the Sry1 locus (Sryo) interacting with DNA (cyan, Figure 5A), it can be seen that substitutions in amino acids 4, 21 and 76 (red, Figure 5A) may have a slight propensity to alter DNA binding stability (Figure 5B) and energy (Figure 5C and Additional file 1: Figure S11).

Srya binds to DNA elements that are known to be bound by hSRY in a sequence specific manner (Figure 6A). Use of a control EBNA DNA (lane 1) is shifted by EBNA protein extract (lane 2), with the shift outcompeted with unlabeled DNA (lane 3). Adding Sryo lysate to this EBNA DNA does not shift the band (lane 4), confirming specificity of DNA sequence for binding. Taking a Sry DNA binding element and adding the EBNA protein did not result in a shift (lane 5) while addition of Sryo lysate did (lane 6). The Sryo binding is competed off with unlabeled Sry DNA (lane 7). The shifting of the DNA was concentration dependent on Srya lysate (Figure 6B-C). This confirms for the first time that Sry protein from Rattus norvegicus can bind to similar DNA sequences as human and mouse.

Srya and Sryy primarily localize to the nucleus of the cell, while Sry $\beta$ is also found in the cytoplasm (Figure 7). Mutating amino acid 21 in Sryo from an Arg to a His (Sryo R21H) resulted in more Sry localization in the cytoplasm, while mutating amino acid 21 in Sry $\beta$ from His to Arg (Sry $\beta$ H21R) abolished the cytoplasmic localization.
This confirms that changes to amino acid 21 can alter cellular localization, while changes at amino acid 38 and 76 likely have minimal change to cellular localization (comparing Sryo and Sryy).

The presence of Thr at amino acid 76 defines the Sry3 subgroup (Sryy-Sry $\zeta$, Figure 2). Sry in all other mammalian species (340 species analyzed to date), every member of the Sox subfamily to which Sry belongs, and rat Sry $\alpha / \beta / \eta / \theta$ proteins all contain a Pro at amino acid 76 . Comparing Sry $\alpha$ to Sryy, only two amino acids vary (38 and 76). The Sry1 promoter is differentially repressed by Sry $\alpha$ and Sryy compared to the control or each other (Figure 8A). When amino acid 76 is mutated in Srya from a Pro to a Thr, this decreases the $S r y 1$ promoter regulation, yielding less repression relative to Sry $\alpha$ (Figure 8B). Changing amino acid 76 in Sryy from a Thr to a Pro increased Sry1 promoter repression relative to Sryy (Figure 8C). Changing amino acid 38 from His to Gln in Sryo had no effect on the promoter regulation (Figure 8B). In contrast, when amino acid 38 of Sryy was changed from Gln to His, promoter repression was decreased relative to Sryy (Figure 8C).

Comparing the proteins from the Sry $4 / 4 A$ loci $(\operatorname{Sryy} / \theta$ proteins) with those of the previously identified Sry proteins, amino acids 4, 21, and 38 are conserved with Sry $\gamma-\zeta$ (the Sry3 loci), while amino acid 76 is shared with Sry $\alpha$, Sry $\beta$ and all other known mammalian Sry proteins (Figure 2 and Additional file 1: Figure S10). Two unique amino acid variations from the rest of the rat Sry proteins are found in the bridge domain of Sryn/ $\theta$. Mutations of Sryo at amino acid 98 (from a Leu to Val designated as Srya L98V, similar to Sry $\theta$ ) showed a trend towards decreased repression of the Sry1 promoter relative to Sry $\alpha$ (Figure 9). A double mutant (similar to Sryn) at amino acid 98 and also 83 (Pro to Ser; Sryo P83S/L98V) showed regulation similar to the single mutant construct (Srya L98V). 


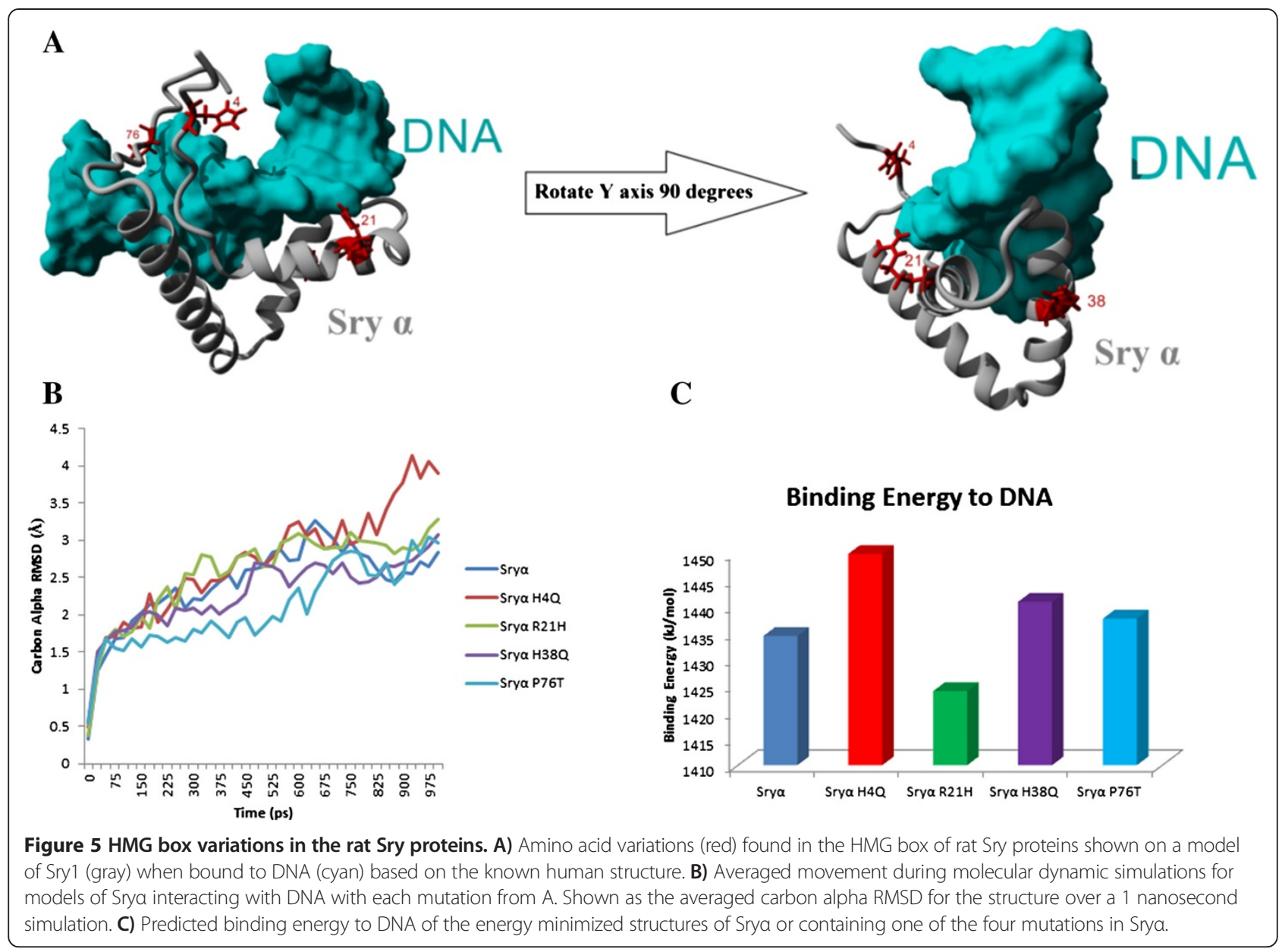

\section{A}

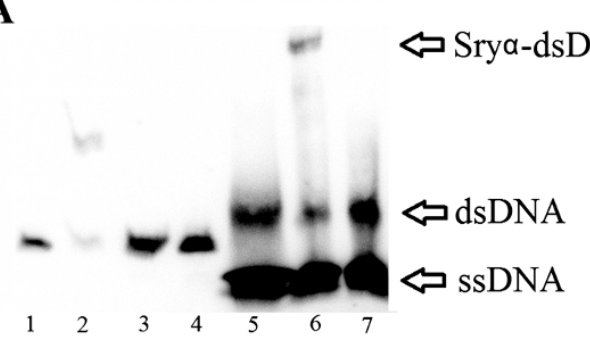

B

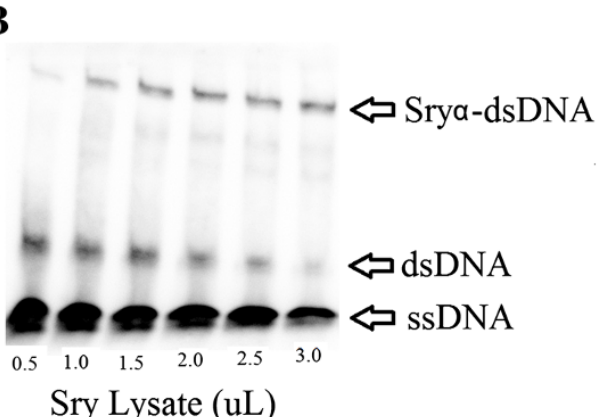

1) Biotin EBNA DNA
2) Biotin EBNA DNA + EBNA Extract
3) Biotin EBNA DNA + EBNA Extract + EBNA DNA
4) EBNA DNA + Sry $\alpha$ lysate (2uL)
5) Biotin Sry DNA + EBNA Extract
6) Biotin Sry DNA + Sry $\alpha$ Lysate $(2 u L)$
7) Biotin Sry DNA + Sry $\alpha$ Lysate $(2 u L)+$ Sry DNA

C

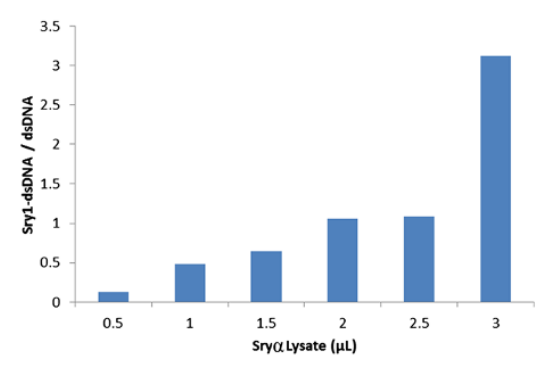

Figure 6 Binding of Srya to a known Sry-DNA binding element. A) Control experiments for Srya specific binding. The protein and DNA identities for each lane can be seen in the box next to the gel. B) Concentration curve for extract amounts of Sry 1 transformed E. coli cell lysates expressing Srya protein. C) Densitometry measurements of the Srya-dsDNA and dsDNA bands mapped relative to lysate volume. 


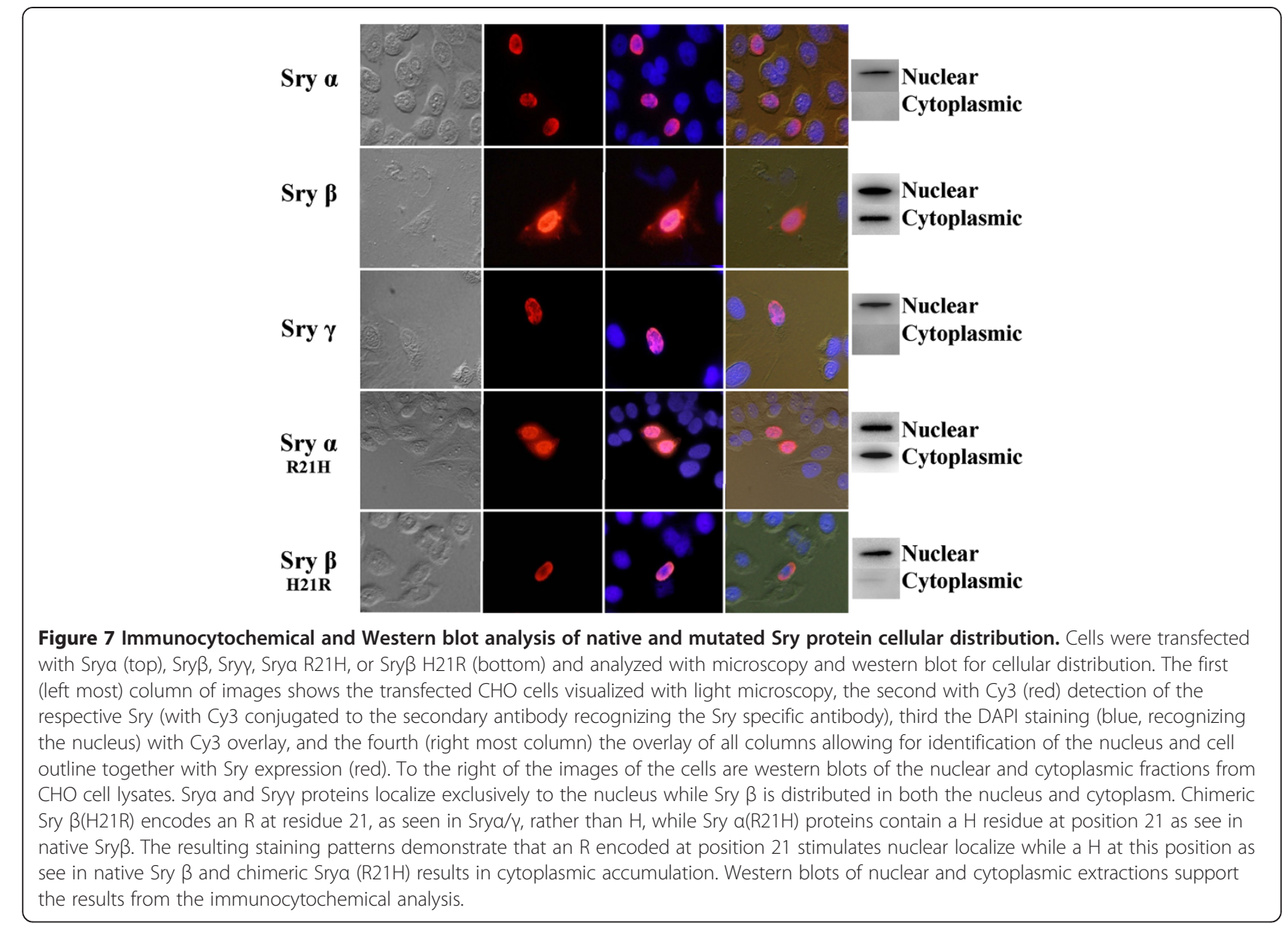

Sry $\alpha$ P83S caused a significant loss of regulation on the Sry1 promoter construct; however, this variant is not found by itself in any of the rat Sry copies.

Sry proteins with different lengths of the Q-rich C-

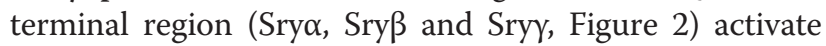
the AR600 promoter construct at various levels compared to the control (Figure 10A). Sry $\beta$ has a deletion of 13 amino acids when compared to Sry $\alpha$ and Sryy (Figure 2). Removing these 13 amino acids from Sry $\alpha$, creating a construct known as Sry $\alpha(\mathrm{del})$, decreased promoter activity compared to the wild type Srya (Figure 10B) yielding similar values as Sry $\beta$. Completely removing the 25 amino acids of the Q-rich region of Sry $\alpha$, known as $\operatorname{Sry} \alpha(-Q R)$, resulted in minimal regulation of the promoter as did a construct containing only the HMG box of Sry $\alpha$ (Figure 10B). Sry $\beta$ with the $13 \mathrm{Q}$ amino acids of Sry $\alpha$ or Sryy added, known as Sry $\beta$ (+QR), increased promoter activity compared to Sry $\beta$, yielding a value similar to Sry $\alpha$ and Sryy (Figure 10C). The complete removal of the Q-rich region of Sry $\beta$, Sry $\beta(-Q R)$, caused a complete loss of promoter regulation. Similar results to mutations of Sry $\alpha$ (Figure 10B) were seen when the deletions were made to Sryy (Figure 9D). Modeling the Q-rich region and the remaining C-terminal end of rat Sry (Figure 11A) shows the locations of variations outside of the HMG box mapped onto the structure of Sry $\alpha$ interacting with DNA (Figure 11B, Additional file 2).

\section{Discussion}

Multiple Sry loci in Rattus norvegicus are known to be expressed [8]. Sequencing of the SHR/Akr rat Y chromosome is under progress by the $\mathrm{Y}$ chromosome project (http://www.genome.gov/25521746). Identifying and labeling all the Sry loci and functional variations are of importance for both annotating Y-chromosome sequence data and for understanding how each of these Sry loci functions. The SHR/Akr strain has been shown to have loci on the Y-chromosome that are associated with blood pressure increases $[13,14]$ and other sympathetic nervous system phenotypes reviewed in [15]. Animals with the Ychromosome of SHR and WKY autosomes have higher blood pressure than WKY males [14]. Studies have revealed the inability to amplify the Sry3 locus, present in SHR, from WKY genomic DNA, suggesting a potential increase in CNV of SHR over WKY [9]. Delivery of the coding sequence of either Sry1 [16] or Sry3 [17] but not Sry2 

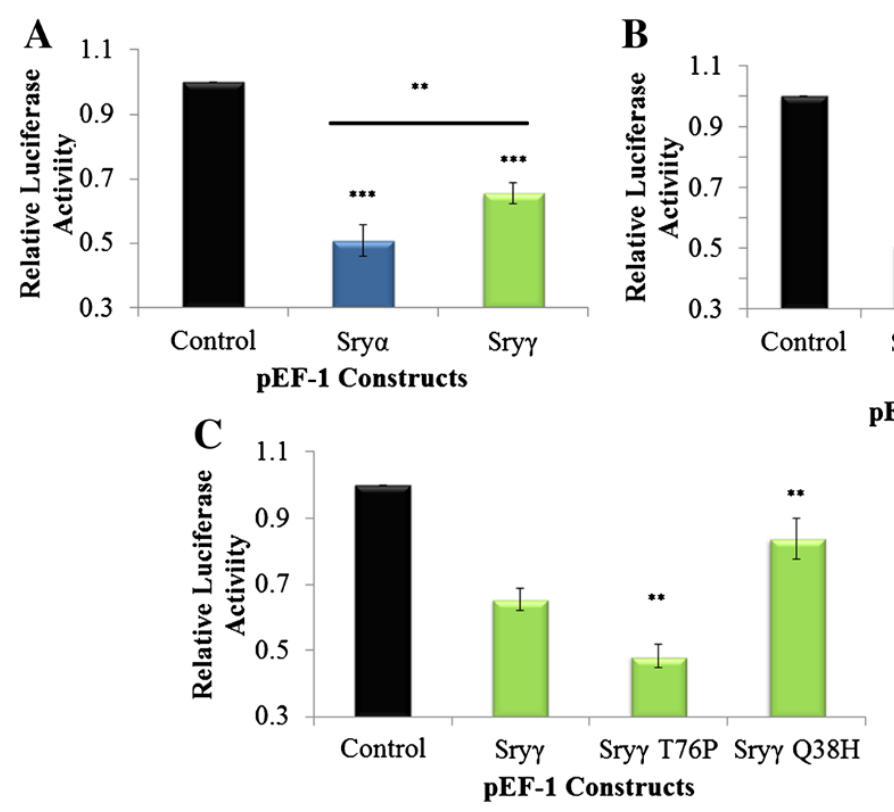

Figure 8 Regulation of the Sry 1 promoter by Srya and Sryp. A) Srya (blue) and Sryy (green) transfected CHO cells significantly repress the Sry 1 promoter construct when compared to empty vector control (black) or each other (bar above Srya and Sryy). B) Srya and mutations of Srya at amino acids 76 (Srya P76T) and 38 (Srya H38Q) transfected into CHO cells all repress the Sry 1 promoter construct when compared to empty vector control (black), with the P76T and not H38Q significantly differing from Srya. C) Sryy and mutations of Sryy at amino acids 76 (Sryy T76P) and 38 (Sryy Q38H) transfected into CHO cells all repress the Sry 1 promoter construct when compared to empty vector control (black), with the T76P and Q38H significantly differing from Sryy. For all figures error bars represent the standard error of the mean and statistical significance is shown as $*=p \leq 0.05, * *=p \leq 0.01, * * *=p \leq 0.001$.

[16] into the kidney of normotensive WKY rats induces a blood pressure increase through the renin-angiotensin system and the sympathetic nervous system. With Sry3 present in SHR but not detected in WKY [10], this additional copy of an Sry gene (Sry3) may be largely

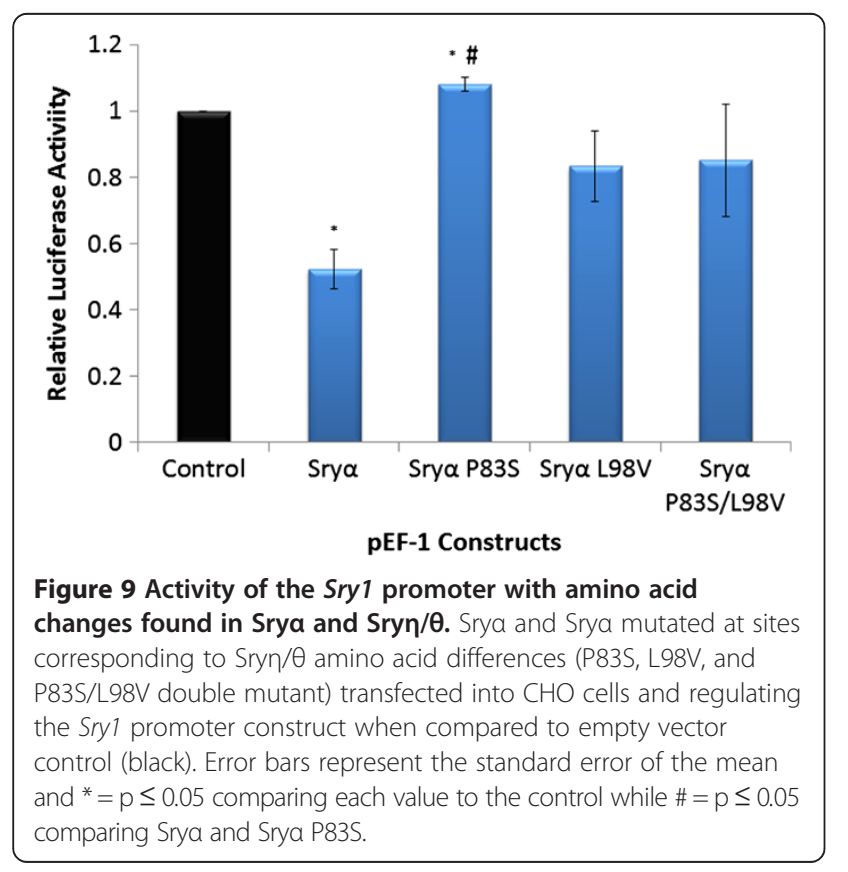

responsible for the blood pressure elevation seen in Y-chromosome crosses of the consomic strains $[13,14]$. Y-chromosome sequence analysis has revealed at least eleven Sry loci on the Y-chromosome of Rattus norvegicus SHR/Akr that code for nine different proteins. It is possible that additional loci exist and have yet to be sequenced; sequencing of the SHR/Akr Y-chromosome is still underway. We do not know which Sry locus codes for testis determination in Rattus norvegicus or if multiple loci contribute to this function. It may be possible that any of the ten Sry loci (excluding the nonHMG Sry) could determine sex if expressed with proper developmental timing. Four new loci were detected in this current study. These were previously unidentified due to an insertion of DNA after the 3' untranslated region in these newly identified loci, preventing PCR amplification with the primer sets previously used. New primer sets and restriction digests allowed us to identify these new loci in both SHR and WKY rats.

Compiled contigs for the Y-chromosome region containing the Sry loci in Rattus norvegicus allow for identification of possible mechanisms of gene duplications. Of the four loci identified in our contigs that are not Sry (Zfy, Med14, Ccdc110, and HMGB1), several are flanked by repetitive elements that may have contributed to locus positioning on the Y-chromosome. An LTR/ERVK element was identified 5' of the start codon of the Med14Y. This 


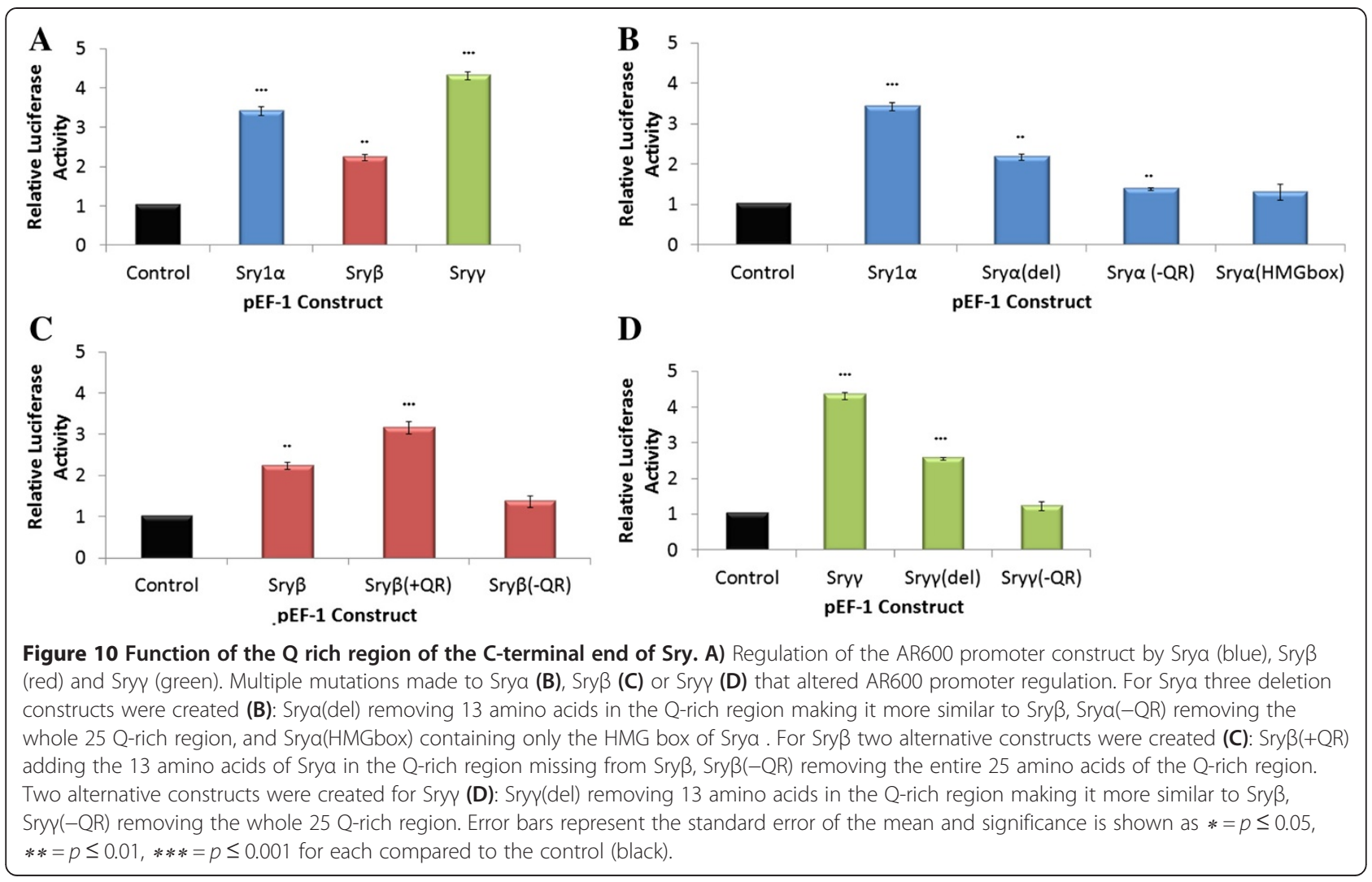

Med14Y is highly homologous to the $\mathrm{X}$-chromosome Med14, however it is missing the normal introns, suggesting retrotransposition of a mature mRNA onto the Y-chromosome of rat. An LTR element has also been identified 3' of the Zfy and 5' of the Ccdc110 loci. Currently we do not know the function or conservation (presence and spatial organization) of these loci on the Y-chromosome in other rat species. Future work will be required to determine the dynamic gene evolution occurring in rat Y-chromosome evolution.

The largest conserved fragment of DNA sequence within the contigs is between Sry4 and Sry $4 A$, with a large region of 3' conservation (around $43 \mathrm{kB}$ ). Analysis of the conservation revealed a LINE L1 element (cyan, Figure 1) conserved at the point where homology is lost; this LINE L1 appears to have the proper sequences to code for proteins of both ORFs required for LINE L1 transposition. Flanking several other loci (Sry3C and Sry3A) are insertions of LINE L1 elements relative to the other loci, suggesting more recent LINE L1 insertions after copy number increased. SOX genes have been shown to regulate the promoters of LINEL1 elements [18] suggesting a potential interplay between Sry and LINE-L1. These elements, as well as sequence variations, may alter the expression of the various loci, as has already been shown [8]. The $S r y 2$ gene is preferentially expressed in adult adrenal glands relative to testis, while the combination of Sry1, Sry3 and Sry3C is expressed at a higher level in the testis relative to adrenal. The $S r y 3 C$ locus shares a high level of conservation with the 3' end of Sry 2 and a lower level with Sry1. These observations suggest that $\mathrm{Sry} 3 \mathrm{C}$ may have resulted from the original duplication event and then further duplicated and differentiated to give the remaining Sry3 subgroup members. Identifying the mechanism of duplication and order of events is complicated by a continual change to all loci after the duplication events occurred. This may be simplified by understanding the organization of the Y-chromosome and Sry sequences in other Rattus norvegicus strains and other rodent species. For example, our initial sequence analysis comparing the Rattus norvegicus and Tokudaia muenninki Sry copies did not reveal any connections between the duplicated copies at either the DNA or amino acid level, indicating that Sry duplication has occurred more than once. Understanding the duplication events in the rat may help to explain duplications of $S R Y$ seen in humans exposed to radiation or with Turner syndrome [6,7].

Amino acid differences among the proteins coded by the multiple Sry loci result in functional variation. From the eleven loci, we predict nine protein sequences (Sryo-Sry $\theta$ and the nonHMGSry). Sry $\beta$ has several amino acid variations in nuclear localization sites (amino acids 4 and 21) and also the C-terminal end (Figure 2 and Figure 11). Sry protein localizes to the nucleus using two different localization signals (NLS) [19]. The first NLS is found as a 


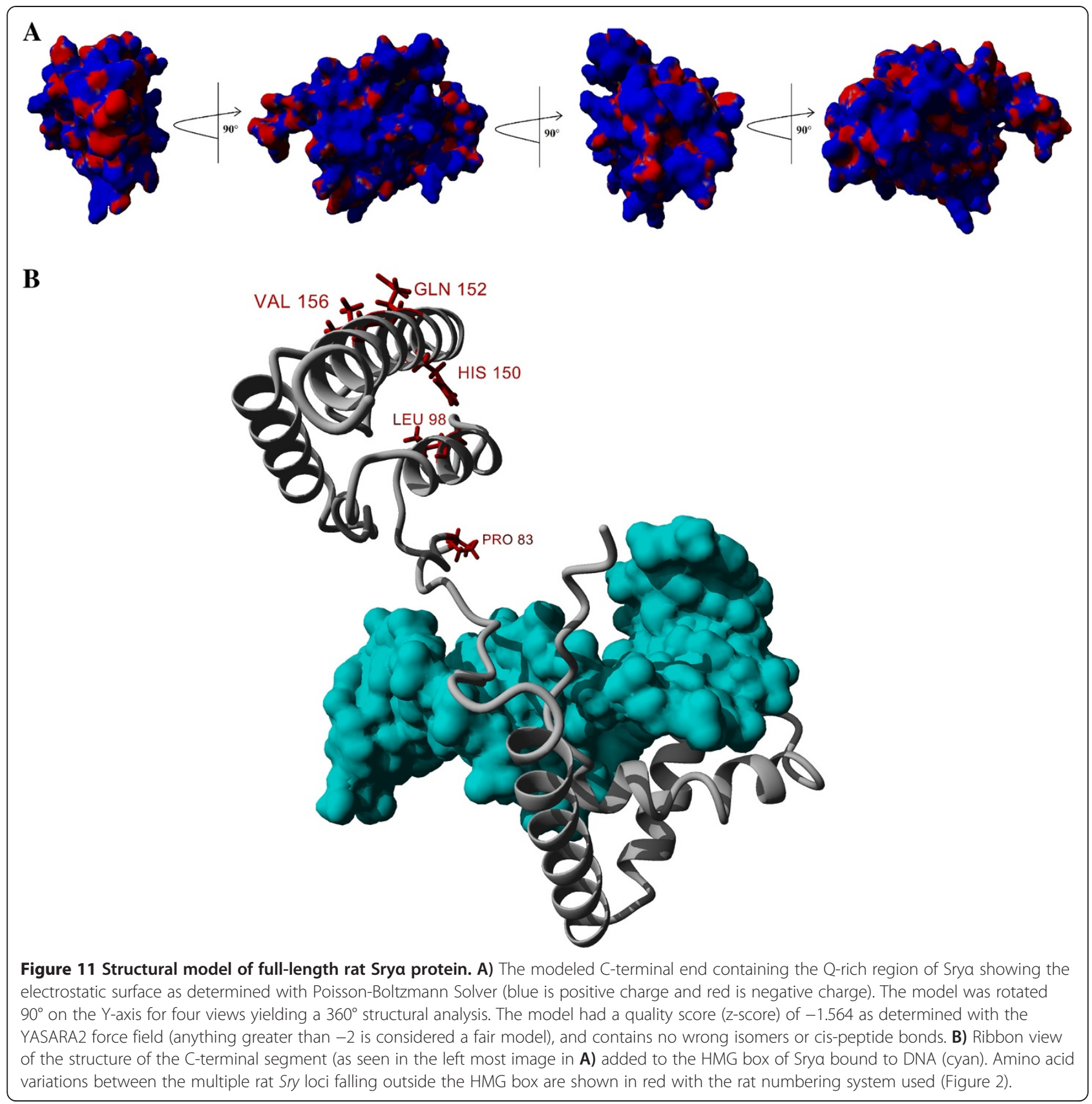

bipartite signal known to interact with calmodulin [20-22]. Amino acid 4 falls into the NLS in the first of the bipartite sequences and amino acid 21 in the second. Mutations of amino acid 21 in Sry $\alpha$ decreased nuclear localization, and models for the interaction between Sry and calmodulin suggest a decreased interaction when amino acid 21 is a His (Additional file 1: Figure S12).

All the Sry3 loci (Sryy- $\zeta$ proteins) contain a threonine at amino acid 76, rather than the normal proline. A proline is found at this amino acid in all human SOX genes (and all other vertebrate and invertebrate Sox genes analyzed to date by our lab) and all mammalian Sry sequences
[23]. Variation at amino acid 76 in hSRY is associated with sex reversal [24]. This suggests a high degree of conservation, likely required for proper DNA bend angle, protein recruitment, and gene regulation [20]. Amino acid 76 falls in the second NLS which is thought to work through importin- $\beta 1$ [25]. Both Sry $\alpha$ and Sryy localize to the nucleus (Figure 7), and changes from a proline to a threonine at amino acid 76 do not seem to alter nuclear localization. Promoter activity assays show that the proline to threonine change in Sry $\alpha$ leads to changes in activity. Modeling approaches and proline to threonine mutations also showed altered regulation of renin-angiotensin system promoters 
[10] in addition to the Sry1 promoter in this study. Mutations on our Sryo and Sryy constructs at amino acid 38 altered promoter regulation for Sryy only. This suggests that changes to amino acid 38 may compensate for the loss of activity seen when also changing amino acid 76 . It should be noted as two amino acids vary between these constructs, Sry $\alpha$ P76T and Sryy Q38H yield the same mutant proteins as do Srya H38Q and Sryy T76P. The Sry1 promoter regulation for these constructs showed no difference when compared to each other, and serve as an internal control to validate that the changes in regulation could only be due to changes at these two amino acids.

Sryn and $\operatorname{Sry} \theta$ proteins (produced from the Sry 4 and Sry $4 A$ loci) show amino acid variation in the bridge domain. The Sry4 genes have not been cloned and analyzed for expression, so Sry $\alpha$ was chosen for mutagenesis. Amino acid 76 (shown to result in significant functional alterations when a Thr and not a Pro) is conserved among Sry $/ \operatorname{Sry} \theta$ and Sry $\alpha$, therefore making Sry $\alpha$ a better choice than the Sryy or Sry $\beta$ protein constructs to use for mutagenesis. Analysis of amino acid variations among the multiple loci, suggests that Sry 4 and Sry $4 A$ are very old loci as they alone (relative to the other Sry copies) share amino acid 83 with mouse (Additional file 1: Figure S10). With the variations of $\operatorname{Sry} \eta$ and $\operatorname{Sry} \theta$ amino acids falling in the bridge domain, they may alter the interaction with proteins known to interact through the bridge domain of Sry, such as the KRAB containing proteins [26], resulting in altered epigenetic gene silencing of $\operatorname{Sry} / \mathrm{Sry} \theta$ regulated genes [27].

The C-terminal end contains the largest area of variation among the Sry proteins of Rattus norvegicus. There are no known structures for regions outside the HMG box of Sry. With the lack of high sequence conservation of the C-terminal end with other species, it is difficult to determine the importance or functionality of this domain. It has been suggested that the C-terminal end can interact with and stabilize DNA binding [28]; however, it is also likely that this domain serves to recruit other proteins to the DNA. Based on the number of charged amino acids on the surface of the C-terminus (Figure 11A), which also contains a hydrophobic packed structure (Additional file 2), interactions with other proteins (yet to be identified) are possible. The stretch of 13 amino acids deleted in Sry $\beta$ alters regulational ability of Sry as does the deletion of the entire Q-rich C-terminal domain. These results support the importance of this region in rat Sry function, even though the region does not share conservation with most other mammalian Sry sequences. It is possible that functions of the Sry N-terminus in all other mammalian species $[29,30]$ have been translocated to the C-terminus of rodent Sry. Since the structure of Sry places both the $\mathrm{N}$ and $\mathrm{C}$-terminus flanking the HMG box in the same spatial area, one could easily be functionally substituted for the other.
Current work is underway to compile and annotate the Y-chromosome of the SHR/Akr strain. In labeling the multiple loci of Sry, care needs to be taken in naming as we show in this study and others that there are functional variations in the proteins, with differential expression patterns of each. Understanding the mechanisms of the gene duplications seen in this animal model may lend insights into the duplication and transpositions of Sry in many human diseases such as sex reversal. Ultimately, studies such as this allow us to begin to understand evolution of the lesser studied Y-chromosome in an animal model to understand complex diseases such as hypertension, while also addressing the evolution of the Y-chromosome in mammals.

\section{Conclusions}

Currently we know of eleven Sry copies on the Rattus norvegicus Y-chromosome with additional copies of Zfy, Med14, Ccdc110, and HMGB1 in this region. Transposable elements seem to play an active role in the duplication and translocation of these genes. The duplication events have led to Sry proteins that have amino acid variations that lead to functional alterations in nuclear localization and transcriptional activity. These results show some of the dynamic processes involved in the evolution of the Y-chromosome and suggest importance in numerous disease models such as hypertension.

\section{Methods}

\section{Identification of Sry proteins}

The sequence of the Sry1 locus (EU984075) was blasted against the NCBI Rattus norvegicus sequences. Protein sequences were translated from BAC clones or sequenced constructs using Expasy translate, and aligned by hand. Several new loci (Sry3BII, Sry4 and Sry4A) were confirmed by PCR using primers specific to these loci, JP1R (5'-ccaaa tacagcaaggctgag) and JF8L (5'tgtaaggggtaaaagctagtatcc) primer set, with Phusion Hot Start II (Thermo Scientific) on both SHR and WKY genomic DNA (cycling conditions: $98^{\circ} \mathrm{C}-3 \mathrm{~min}, 98^{\circ} \mathrm{C}-30 \mathrm{sec}, 56.8^{\circ} \mathrm{C}-30 \mathrm{sec}, 72^{\circ} \mathrm{C}-45 \mathrm{sec}$, repeats steps $2-435$ times, $72^{\circ} \mathrm{C}-5 \mathrm{~min}, 4^{\circ} \mathrm{C}$-hold). Reactions were run on $1 \%$ agarose gels and the bands were isolated using IBI gel extraction kit (MidSci). Fragments were used in either restriction digest with $A f l$ II or a nested PCR using L-BamH1/KozakSry (ctaggatccgaaccatggagggcc atgtcaag) and R-Not1-StopcodonSry (ctagcggccgctcgtggaac tggtgctgct) with GoTaq polymerase (Promega; cycling conditions: $94^{\circ} \mathrm{C}-4 \mathrm{~min}, 94^{\circ} \mathrm{C}-1 \mathrm{~min}, 60^{\circ} \mathrm{C}-35 \mathrm{sec}, 72^{\circ} \mathrm{C}$ $1 \mathrm{~min}$, repeat steps $2-430$ times, $72^{\circ} \mathrm{C}-7 \mathrm{~min}, 4^{\circ} \mathrm{C}$-hold).

\section{Contig design, repeat detection, sequence alignments, and phylogenetics}

Contigs were built using the sequenced BACs of Table 1. In short, all sequences were compiled with Sequencher 4.5 (Gene Codes) using max inputs for alignments. For 
short incomplete BACs, the ends (at least 3000 base pairs) were removed to exclude low sequence depth areas. The previously identified Sry sequences were then aligned to the contig with $100 \%$ identity. Repetitive sequences were identified using RepeatMasker [31] with abblast, default speed, rat as the DNA source, no contamination checks, and simple repeats not masked. To compare the rat transposable elements on the Y-chromosome, mouse and human Y-chromosome sequences flanking the respective Sry were used (using the DNA source of the respective species for the RepeatMasker analysis). The Sry loci were aligned to each of the other loci to identify the conserved fragment size using Clustal Omega [32] with default settings. A minimal conserved fragment size around Sry was identified for all the Sry loci present in the contigs. Phylogenetics were performed using MEGA-5 [33] on this minimal fragment or the ORF for each of the rat Sry loci with $h S R Y$ [GenBank: CCDS14772] or mSry [GenBank: CCDS30545] using maximum likelihood with the JTT model and 500 bootstrap replications.

\section{Mutagenesis and promoter cloning}

Mutations of the rat Sry pEF-1 expression vectors were created with site directed mutagenesis using Phusion Hot start Taq (Thermo Scientific). The respective primer set for each mutation (F-Sry1H38Q: atcagcaagcagctgg gatatcagtgg, R-Sry1H38Q: ctctgaattctgcatgctgggattctg; F-Sry1P76T: aaatatcagactcatcgaagggttaaagtg, R-Sry1P76T: atagtttggatatttctctctgtgtagggt; F-Sry1P83S: tatactttgcagcgt gaagt, R-Sry1P83S: actcctctgtgacactttaa; F-Sry1L98V: ctgcaa tgggacaacaacct, R-Sry1L98V: caggttgtacacttttgttgagg; FSry3Q38H: atcagcaagcatctgggatatcagtgg, R-Sry3Q38H: ctctgaattctgcatgctgggattctg; F-Sry3T76P: aaatatcagcct catcgaagggttaaagtg, R-Sry3T76P: atagtttggatatttctctctg tgtagggt; F-hSRYQ93H: atcagcaagcatctgggataccagtgg, R-hSRYQ93H: ctctgagtttcgcattctgggattctc; F-hSRYP131T: aagtatcgaactcgtcggaaggcgaagatg, R-hSRYP131T: ataattcggg tattctctctgtgcatggc) were phosphorylated with T4 polynucleotide kinase (Fermentas) and used in PCR. T4 DNA ligase (Fermentas) was used to ligate linear vectors and these were transformed into TAM-1 competent E. coli (Active Motif). Sry $\alpha / \gamma(\mathrm{del})$ constructs were created by amplifying Sry from each construct with L-BamH1/ KozakSry and R-Not1-StopcodonSry and digested with Cvi QI which cuts at base pair 294. The C-terminal end of $\operatorname{Sry} \beta$ (containing a 13 amino acid deletion from Sry $\alpha / \gamma$ ) was ligated together with the N-terminus of Sry $\alpha / \gamma$. For $\operatorname{Sry} \beta(+Q R)$ the $N$-terminus of $\operatorname{Sry} \beta$ was ligated with the 13 amino acid larger fragment of Srya. An HMG only construct (Sry $\alpha($ HMGbox)) was created by amplifying Srya with L-BamH1/KozakSry and R-SryXbaBoxOnly (ctctagactgtggcactttaaccc), followed by $\mathrm{T} 4$ ligation to recircularize the vector. Constructs without the C-terminal Q-rich region were created by PCR with L-BamH1/
KozakSry and R-SryXba-QR (ctctagatgggtatccagtgg) generating a 142 amino acid protein from each Sry (Sryo $(-Q R)$, $\operatorname{Sry} \beta(-Q R)$, $\operatorname{Sry\gamma }(-Q R))$.

The two promoter constructs used in luciferase assays were the Sry1 and AR600 constructs. A pGL3 rat Sry1 promoter construct $(-3317 /+10,+1$ designating the proposed transcriptional start site) was created by amplification from cloned Sry1 DNA [GenBank: KC215142] with L-Sry1NheI (5'-CTATGCTAGCTCCATACCAAGAAGGCAGTTG-3') and R-Sry1HindIII (5'-CGCAAGCTTAAACCCCTGTG GATTGTAAATG-3'). The rat Sry1 promoter contains multiple potential Sry binding sites as determined by MatInspector (Genomatix). This fragment was cloned into pGL3 with Nhe I and Hind III restriction digest. The pGL3 AR600 construct (containing the 5' UTR of AR, with several potential Sry binding sites) was created by PCR with R-ARNco (gtaccatggtttagcttgtctctagcttccacc) and LARSma600 (cacccgggtaactccctttggctga) and cloned in with Nco I and Sma I restriction digest and ligation. All clones and mutations were sequence confirmed using BigDye Terminator chemistry on ABI 3130xl genetic analyzer (Applied Biosystems).

\section{Electrophoretic mobility shift assays (EMSA)}

Sry1 DNA was inserted into the pIVEX 2.4 with GoTaq (Promega) PCR using 5'- gcgcccgggctagtggaactggtgct and 5'- gcggcccatggagggccatgtcaag with $\mathrm{NcoI}$ and Sma I digests, followed by T4 ligation. Vector was transformed into BL21 (DE3) competent E. coli (NEB). A single isolated colony of cells was inoculated into $5 \mathrm{~mL}$ terrific broth containing $50 \mathrm{ug} / \mathrm{mL}$ Ampicillin and grown to $\mathrm{OD}_{600}$ of 0.8 at $37^{\circ} \mathrm{C}$. Cells were induced with $0.75 \mathrm{mM}$ IPTG and incubated at $37^{\circ} \mathrm{C}$ for three hours. Cells were collected at $5000 \times \mathrm{g}$ for $10 \mathrm{~min}$ and frozen at $-80^{\circ} \mathrm{C}$ until lysis. Cells were lysed with $1 \mathrm{~mL}$ of $1 \times$ CelLytic B (Sigma-Aldrich), $2 \mathrm{mg} / \mathrm{mL}$ Lysozyme, $0.25 \mathrm{mM}$ Leupeptin, $1 \mathrm{mM}$ PMSF, 50 Units DNase, $25 \mathrm{mM} \mathrm{NaF}, 25 \mathrm{mM} \mathrm{MgCl}$ in phosphate buffered imidazole. Cells were passed through a 25 gauge needle multiple times to complete lysis and the lysate was centrifuged at $10,000 \times \mathrm{g}$ for $20 \mathrm{~min}$.

Freshly annealed primers (5'-CATACTGCGGGGGTG ATTGTTCAGGATCATACTGCG-3' and antisense), containing a $5^{\prime}$ conjugated biotin (IDT) on the sense strand (primers were previously used by another lab to confirm hSRY-DNA binding [34]) were prepared in primer annealing buffer (10 mM Tris, $1 \mathrm{mM}$ EDTA, $100 \mathrm{mM} \mathrm{NaCl}$, $\mathrm{pH}$ 8.0) at a final concentration of $10 \mu \mathrm{M}$. Annealed primers were diluted to $250 \mathrm{fmol} / \mu \mathrm{L}$. Non-denaturing TBE polyacrylamide gels $(6 \%)$ were casted in a $0.75 \mathrm{~mm}$ spaced glass cassette (Bio-Rad) with a 10 well comb and preelectrophoresed for $1 \mathrm{hr}$ at $100 \mathrm{~V}$ in $0.5 \times \mathrm{TBE}$. Control binding experiments were setup using the LightShift EMSA optimization and control kit (Thermo). All reactions contained $2 \mu \mathrm{L} 10 \times$ binding buffer, $1 \mu \mathrm{L} 50 \%$ glycerol, 
$1 \mu \mathrm{L}$ Poly $(\mathrm{dI}-\mathrm{dC})$, and $1 \mu \mathrm{L} 1 \% \mathrm{NP}-40$. For the respective reactions, $2 \mu \mathrm{L}$ Biotin-EBNA control DNA, $2 \mu \mathrm{L}$ Unlabeled EBNA control DNA, $1 \mu \mathrm{L}$ EBNA overexpression extract, $2 \mu \mathrm{L}$ Biotin-Sry-DNA, $2 \mu \mathrm{L}$ Unlabeled-Sry-DNA (2 pM), and $2 \mu \mathrm{L}$ Sry $\alpha$ cell lysate sample sizes were used. All reactions were brought to $20 \mu \mathrm{L}$ total with molecular water. Sry $\alpha$ lysates ranging from 0.5 to $3 \mu \mathrm{L}$ in $0.5 \mu \mathrm{L}$ increments were used to show a concentration dependence of DNA binding. Reactions were incubated at room temperature for $20 \mathrm{~min}$. Samples were run on a TBE gel at $100 \mathrm{~V}$ for 45 min. A Biodyne B Nylon Membrane (Thermo) was soaked in $0.5 \times \mathrm{TBE}$ for $10 \mathrm{~min}$. When electrophoresis was complete, the gel was transferred to the membrane in a semi-dry horizontal transfer system at $75 \mathrm{~mA}$ for $30 \mathrm{~min}$. The membrane was then dried for twenty minutes at room temperature, cross linked using UV light and detection was performed as recommended in the LightShift Chemiluminescent EMSA kit (Thermo). ImageJ (NIH) was used for densitometry analysis.

\section{Nuclear localization}

CHO-K1 cells $\left(1.25 \times 10^{4}\right.$ cells $\left./ \mathrm{cm}^{2}\right)$ used for immunocytology were seeded onto LabTek ${ }^{\mathrm{Tm}} 16$ well glass chamber slides $\left(\mathrm{Nunc}^{\mathrm{TM}}\right)$ in HAM's F12K medium (Sigma) supplemented with $10 \mathrm{mM}$ HEPES, $30 \mathrm{mM}$ sodium bicarbonate and $10 \%$ fetal bovine serum (Atlanta Biologicals) in a humidified atmosphere at $37^{\circ} \mathrm{C}$ with $5 \% \mathrm{CO}_{2}$. After 24 hours cells were transfected with $300 \mathrm{ng}$ plasmid DNA (Sry pEF1expression vector) using $1 \mu \mathrm{l}$ ExGen500 in $20 \mu \mathrm{l}$ $150 \mathrm{mM} \mathrm{NaCl}$. After 24 hours of incubation all chambers were washes twice with $1 \times$ PBS and fixed for 5 min in ice cold methanol. Cell were incubated $25 \mathrm{~min}$ in blocking solution (1× PBS containing 10\% normal rabbit serum and $3 \%$ nonfat dry milk) followed by incubating one hour with the primary antibodies, goat anti-Myc epitope (Bethyl Laboratories, Inc.) or goat anti-mouse Sry E-19 (Santa Cruz Biotechnology, Inc.) diluted 1:450 and 1:100 respectively in diluted blocking solution ( $2 \%$ normal rabbit serum, $0.6 \%$ nonfat milk) at $22^{\circ} \mathrm{C}$. After four washes with $1 \times \mathrm{PBS}$, the secondary antibody, a rabbit anti-goat IgG-Cy3 $3^{\mathrm{Tm}}$ conjugate (Sigma-Aldrich, Inc.) diluted 1:3500 in blocker diluted to $4 \%$ normal rabbit serum, was added in $1.2 \%$ nonfat milk and incubated $45 \mathrm{~min}$ at $37^{\circ} \mathrm{C}$. After two washes in $1 \times$ PBS, VectaShield mounting medium containing DAPI (Vector Laboratories) was applied and images were captured using a broad range excitation filter $(530-550 \mathrm{~nm})$ on an Olympus BX60 with DP71 digital camera and DP Controller software. Controls to ensure antibody specificity included $\mathrm{CHO}$ transfected as described above with Sry $\alpha$ incubated with normal goat serum or PBS in place of a primary antibody. In all experiments at least 12-25 stained cells were observed per transfection.

$\mathrm{CHO}-\mathrm{K} 1$ cells were grown to $1.0 \times 10^{5}$ cells $/ \mathrm{cm}^{2}$ on $100 \mathrm{~mm}$ plates $\left(\mathrm{Nunc}^{\mathrm{TM}}\right)$ as described previously. Each plate was transfected with $7.5 \mu \mathrm{g}$ respective Sry pEF1 expression vector that was complexed with $25 \mu \mathrm{l}$ ExGen500 and $150 \mathrm{mM} \mathrm{NaCl}$ was used to bring the total reaction volume to $1 \mathrm{~mL}$. Complexes were applied to $\mathrm{CHO}$ in $9 \mathrm{~mL}$ fresh medium and centrifuged at $280 \times \mathrm{g} 5 \mathrm{~min}$. Following a 24 hour incubation, medium was removed, plates were washed with $1 \times$ PBS and cells were trypsinized, pelleted $(280 \times$ g, $5 \mathrm{~min}$.) and cytoplasmic and nuclear proteins were separated using the reagents and protocol supplied in the ProteoJET ${ }^{\mathrm{Tm}}$ Cytoplasmic and Nuclear Protein Extraction Kit (Fermentas). Fractions generated were quantified by Bradford Assay (Thermo) and then subjected to SDS PAGE and western blot analysis.

Cytoplasmic and nuclear extracts $(20 \mu \mathrm{g})$ were separated on $13.5 \%$ polyacrylamide gels and proteins were semidry transferred (1 $\mathrm{mAmp} / \mathrm{cm}^{2}$ ) to PVDF membranes. Blots were blocked $1 \mathrm{hr}$ at room temperature in $1 \times$ TBS containing 5\% nonfat dry milk and $0.1 \%$ Tween-20. Primary antibodies used to detect Sry proteins include a goat antimouse Sry E-19 (Santa Cruz Biotechnology, Inc. ) and a goat anti-Myc epitope (Bethyl Laboratories, Inc. Laboratories). Both antibodies were diluted in blocking solution at 1:300 and 1:1000 respectively and incubated for at least $1 \mathrm{hr}$ at room temperature. Following two washes in $1 \times$ PBS, the secondary antibody, donkey anti-goat HRP conjugate (Bethyl Laboratories, Inc. Laboratories) was diluted 1:6,000 in blocking solution and incubated $1 \mathrm{hr}$ at room temperature. Bands were detected using SuperSignal West Pico Chemiluminescent Substrate (Thermo Fisher Scientific Inc.).

\section{Cotransfections and luciferase assays}

Transfection into $\mathrm{CHO}-\mathrm{K} 1$ cells was performed using $500 \mathrm{ng}$ pGL3 reporter vector, $50 \mathrm{ng}$ of pEF1 expression vector, 500 pg Renilla control vector and $2 \mathrm{uL}$ Turbofect (Fermentas) into $5 \times 10^{4}$ cells preplated in a 24 well plate 24 hours prior to transfections. Cells were lysed 24 hours post transfection and luciferase assays performed with Dual-Luciferase reported assay system (Promega) according to the manufacturer's instructions. Statistics were performed using JMP software with statistical significance of $\mathrm{p}<0.05$. ANOVAs were performed followed by individual student's t-tests. All error bars are presented as the standard error of the mean.

\section{Modeling protein structures and molecular dynamic simulations}

Models of rat Sry tertiary structure were created using I-TASSER [35] and aligned to DNA using the PDB structure 1j46 of human SRY [36] and energy minimized with YASARA [37] with water at $0.998 \mathrm{~g} / \mathrm{mL}$ and AMBER03 force field [38]. Models for the C-terminal end of Sry $\alpha$ were created with QUARK [39]. The ten models were run in molecular dynamic simulations for 2 nanoseconds and 
observed for energy and residue movement. The best model (model 4) as determined by maximal hydrophobic packing in md simulation, model quality (determined with the knowledge-based potential of YASARA2), and energy minimization was manually added onto the model of the HMG box bound to DNA, forming the peptide bond, followed by energy minimizations using the AMBER03 force field in water.

\section{Availability of supporting data}

"The data sets supporting the results of this article are available in the GenBank repository, [Accession codes: KC215139, KC215140, KC215141, KC215142; http://www. ncbi.nlm.nih.gov/genbank/]".

\section{Additional files}

Additional file 1: Supporting data and sequence alignments for the conclusions of the paper.

Additional file 2: Model of the HMG box of Srya bound to DNA with the additional C-terminal domain of Srya.

\section{Competing interests}

The authors declare that they have no competing interests.

\section{Authors' contributions}

JWP performed Y-chromosome sequence analysis, newly identified copy number variation detection and sequencing, EMSA and wrote the manuscript. ACU performed nuclear localization studies. JWP and ACU both performed luciferase assays. NM and DP helped in the identification of the new Sry copies, SS in the EMSA assays, and CS in characterization of the Sry 1 promoter sequence. MET and AM advised on all studies and contributed significantly to the development of research ideas / conclusions of data. All authors have read and approved the manuscript.

\section{Acknowledgments}

BAC clones were mapped and sequenced as part of the rat $Y$ chromosome sequencing project (http://www.genome.gov/25521746), a collaboration between the Whitehead Institute (Helen Skaletsky, Sara Zaghlul, Laura G. Brown, Jennifer F. Hughes, David C. Page) and the Baylor College of Medicine Human Genome Sequencing Center. We thank this group for help in analysis and for providing Tiling paths of the BAC sequences. This research was supported by grants from the National Institutes of Health (1R01 HL71579-01A3), American Heart Association (Predoctoral fellowship 11PRE7380033 to JWP), Ohio Board of Regents Choose Ohio First, and The University of Akron.

\section{Author details}

${ }^{1}$ Department of Biology, The University of Akron, 302 Buchtel Commons, 44325-3908 Akron, OH, USA. ${ }^{2}$ Program in Integrated Bioscience, The University of Akron, 44325 Akron, OH, USA. ${ }^{3}$ Human and Molecular Genetics Center, Medical College of Wisconsin, 53226 Milwaukee, WI, USA. ${ }^{4}$ Department of Mathematics and Science, Walsh University, North Canton, $\mathrm{OH}, 44720$, USA.

Received: 22 March 2013 Accepted: 12 November 2013

Published: 14 November 2013

\section{References}

1. Koopman P, Gubbay J, Vivian N, Goodfellow P, Lovellbadge R: Male development of chromosomally female mice transgenic for SRY. Nature 1991, 351:117-121.

2. Nagamine CM: The testis-determining gene, SRY, exists in multiple copies in Old World rodents. Genet Res 1994, 64:151-159.

3. Biachi NO, Biachi MS, Bailliet G, de la Chapette A: Characterization and sequencing of the sex determining region $Y$ gene (Sry) in Akodon
(Cricetidea) species with sex reversed females. Chromosoma 1993, 102:389-395.

4. Lundrigan BL, Tucker PK: Evidence for multiple functional copies of the male sex-determining locus, Sry, in African murine rodents. J Mol Evol 1997, 45:60-65.

5. Bullejos M, Sanchez A, Burgos M, Jimenez R, Diaz de la Guardia R: Multiple mono- and polymorphic Y-linked copies of the SRY HMG-box in Microtidae. Cytogenet Cell Genet 1999, 86:46-50.

6. Premi S, Srivastava J, Chandy SP, Ahmad J, Ali S: Tandom duplication and copy number polymorphism of the SRY gene in patients with sex chromosome anomalies and males exposed to natural background radiation. Mol Hum Reprod 2006, 12:113-121.

7. Premi S, Srivastava J, Panneer G, Ali S: Startling mosaicism of the Y-chromosome and tandem duplication of the SRY and DAZ genes in patients with turner syndrome. PLoS One 2008, 3:e3796.

8. Turner ME, Martin C, Martins AS, Dunmire J, Farkas J, Ely DL, Milsted A: Genomic and expression analysis of multiple Sry loci from a single Rattus norvegicus Y chromosome. BMC Genet 2007, 8:11.

9. Turner ME, Farkas J, Dunmire J, Ely D, Milsted A: Which Sry locus is the hypertensive Y chromosome locus? Hypertension 2009, 53:430-435.

10. Prokop JW, Watanabe IKM, Turner ME, Underwood AC, Martins A, Milsted A: From rat to human, regulation of renin-angiotensin system genes by Sry. Int J Hypertens 2012, 2012:724240.

11. Sudbeck Scherer P: Two independent nuclear localization signals are present in the DNA-binding high-mobility group domains of SRY and SOX9. J Biol Chem 1997, 272:27848-27852.

12. Sim H, Rimmer K, Kelly S, Ludbrook LM, Clayton AHA, Harley VR: Defective calmodulin-mediated nuclear transport of the sex-determining region of the Y chromosome (SRY) in XY sex reversal. Mol Endocrinol 2005, 19:1884-1892.

13. Ely DL, Turner ME: Hypertension in the spontaneously hypertensive rat is linked to the $Y$ chromosome. Hypertension 1990, 16:277-281.

14. Ely DL, Daneshvar, Turner ME, Johnson ML, Salisbury RL: The hypertensive $\mathrm{Y}$ chromosome elevates blood pressure in the F11 normotensive rats. Hypertension 1993, 21:1071-1075.

15. Turner ME, Ely D, Prokop J, Milsted A: Sry, more than testis determination? Am J Physiol Regul Integr Comp Physiol 2011, 301:R561-R571.

16. Ely D, Milsted A, Dunphy G, Boehme S, Dunmire J, Hart M, Toot J, Martins A, Turner M: Delivery of Sry1, but not Sry2, to the kidney increases blood pressure and sns indices in normotensive wky rats. BMC Physiol 2009, 9:10.

17. Ely D, Boehme S, Dunphy G, Hart M, Chiarappa F, Miller B, Martins AS, Turner M, Milsted A: The Sry3 Y chromosome locus elevates blood pressure and reninangiotensin system indexes. Gend Med 2011, 8:126-138.

18. Tchenio T, Casella Heidmann JT: Members of the SRY family regulate the human LINE retrotransposons. Nucleic Acids Res 2000, 28:411-415.

19. Sudbeck P, Scherer G: Two independent nuclear localization signals are present in the DNA-binding high-mobility group domains of SRY and SOX9. J Biol Chem 1997, 272:27848-27852.

20. Harley VR, Lovell-Badge R, Goodfellow PN, Hextall PJ: The HMG box of SRY is a calmodulin binding domain. FEBS Lett 1996, 391:24-28.

21. Hanover JA, Love DC, Prinz WA: Calmodulin-driven nuclear entry: trigger for sex determination and terminal differentiation. J Biol Chem 2009, 284:12593-12597.

22. Kaur G, Delluc-Clavieres A, Poon IK, Forwood JK, Glover DJ, Jans DA: Calmodulin-dependent nuclear import of HMG-box family nuclear factors: Importance of the role of SRY in sex reversal. Biochem J 2010, 430:39-48.

23. Prokop JW, Leeper TC, Duan ZH, Milsted A: Amino acid function and docking site prediction through combining disease variants, structure alignments, sequence alignments, and molecular dynamics: a study of the HMG domain. BMC Bioinforma 2012, 13(Suppl 2):S3.

24. Lundberg $Y$, Ritzen $M$, Harlin J, Wedell A: Novel missense mutation (P131R) in the HMG box of SRY in XY sex reversal. Hum Mutat 1998, 11(Suppl 1):S328-S329.

25. Forwood JK, Harley V, Jans DA: The C-terminal nuclear localization signal of the sex-determining region $Y$ (SRY) high mobility group domain mediated nuclear import through importin beta 1. J Biol Chem 2001, 276:46575-46582.

26. Oh HJ, Li Y, Lau YF: Sry associated with the heterochromatin protein 1 complex by interacting with a KRAB domain protein. Biol Reprod 2005, 72:407-415 
27. Peng $\mathrm{H}$, Ivanov AV, Oh HJ, Lau YF, Rauscher FJ 3rd: Epigenetic gene silencing by the SRY protein is mediated by a KRAB-O protein that recruits the KAP1 co-repressor machinery. J Biol Chem 2009, 284:35670-35680

28. Sanchez-Moreno I, Coral Vazquez R, Mendez JP, Canto P: Full-length SRY protein is essential for DNA binding. Mol Hum Reprod 2008, 14:325-330.

29. Desclozeaux M, Poulat F, de Santa Barbara P, Capony JP, Turowski P, Jap P, Mejean C, Moniot B, Boizet B, Berta P: Phosphorylation of an N-terminal motif enhances DNA-binding activity of the human SRY protein. J Biol Chem 1998, 273:7988-7995.

30. Domenice S, Yumie Nishi M, Correia Billerbeck AE, Latronico AC, Aparecida Medeiros M, Russell AJ, Vass K, Marino Carvalho F, Costa Frade EM, Prado Arnhold IJ, Bilharinho Mendonca B: A novel missense mutation $(\mathrm{S} 18 \mathrm{~N})$ in the $5^{\prime}$ non-HMG box region of the SRY gene in a patient with partial gonadal dysgenesis and his normal male relatives. Hum Genet 1998, 102:213-215.

31. Smit AFA, Hubley R, Green P: RepeatMasker Open-3.0. 1996-2010. http:// www.repeatmasker.org.

32. Sievers F, Wilm A, Dineen DG, Gibson TJ, Karplus K, Li W, Lopez R, McWilliam H, Remmert M, Söding J, Thompson JD, Higgins D: Fast, scalable generation of high-quality protein multiple sequence alignments using Clustal Omega. Mol Syst Biol 2011, 7:539.

33. Tamura K, Peterson D, Peterson N, Stecher G, Nei M, Kumar S: MEGA5: molecular evolutionary genetics analysis using maximum likelihood, evolutionary distance, and maximum parsimony methods. Mol Biol Evol 2011, 28:2731-2739

34. Phillips NB, Jancso-Radek A, Ittah V, Singh R, Chan G, Haas E, Weiss MA: SRY and human sex determination: the basic tail of the HMG Box functions as a kinetic clamp to augment DNA bending. J Mol Biol 2006, 358:172-192.

35. Roy A, Kucukural A, Zhang Y: I-TASSER: a unified platform for automated protein structure and function prediction. Nat Protoc 2010, 5:725-738.

36. Murphy EC, Zhurkin VB, Louis JM, Cornilescu G, Clore GM: Structural basis for SRY-dependent 46-X, Y sex reversal: modulation of DNA bending by a naturally occurring point mutation. J Mol Biol 2001, 312:481-499.

37. Krieger E, Darden T, Nabuurs SB, Finkelstein A, Vriend G: Making optimal use of empirical energy functions: force-field parameterization in crystal space. Proteins 2004, 57:678-683.

38. Duan Y, Wu C, Chowdhury S, Lee MC, Xiong G, Zhang W, Yang R, Cieplak P, Luo R, Lee T, Caldwell J, Wang Kollman J: A point-charge force field for molecular mechanics simulations of proteins based on condensed-phase quantum mechanical calculations. J Comput Chem 2003, 24:1999-2012.

39. Xu D, Zhang Y: Ab initio protein structure assembly using continuous structure fragments and optimized knowledge-based force fields. Proteins 2012, 80:1715-1735.

\section{doi:10.1186/1471-2164-14-792}

Cite this article as: Prokop et al: Analysis of Sry duplications on the Rattus norvegicus Y-chromosome. BMC Genomics 2013 14:792.

\section{Submit your next manuscript to BioMed Central and take full advantage of:}

- Convenient online submission

- Thorough peer review

- No space constraints or color figure charges

- Immediate publication on acceptance

- Inclusion in PubMed, CAS, Scopus and Google Scholar

- Research which is freely available for redistribution

Submit your manuscript at www.biomedcentral.com/submit 